\title{
Determination of Polymorphisms in the GDF5 and EPS8 Genes by HRM Analysis in Holstein Cattle
}

\author{
Zeynep Sonmez ${ }^{1}$ and Memis Ozdemir ${ }^{2, *}$ \\ ${ }^{1}$ Department of Animal Science, Faculty of Agriculture, Igdir University, 76000 \\ Igdir, Turkey \\ ${ }^{2}$ Department of Animal Science, Faculty of Agriculture, Ataturk University, 25240 \\ Erzurum, Turkey
}

\begin{abstract}
A B S T R A C T
The aim of this study was to determine new polymorphisms in GDF5 (growth differentiation factor $5(C D M P-1)$ ) and EPS8 (epidermal growth factor receptor substrate 8). After the PCR analysis of the identified gene regions of 72 head Holstein cattle, samples were separated by the high-resolution melting analysis (HRMA), and sequence analysis was applied to some randomly selected samples. New polymorphisms were identified in the determined genes and gene regions as a result of the sequence analysis. In the $1^{\text {st }}$ exon of the EPS 8 gene, 9 polymorphic regions were identified as g. $94554132 \mathrm{C}>\mathrm{T}$, g. $94554252 \mathrm{G}>\mathrm{C}$, g. $94554348 \mathrm{~T}>\mathrm{G}$, g. $94554354 \mathrm{C}>\mathrm{G}$, g. $94554372 \mathrm{C}>\mathrm{G}$, g. $94554389 \mathrm{~A}>\mathrm{G}, 94554392 \mathrm{C}>\mathrm{G}$, $94554399 \mathrm{~A}>\mathrm{G}$, and $94554439 \mathrm{C}>\mathrm{G}$. Within the region examined in the $2^{\text {nd }}$ exon of the EPS 8 gene, only the g.94555920T $>\mathrm{G}$ polymorphism was identified. In the $1^{\text {st }}$ exon of the $G D F 5$ gene, the g. $65340723 \mathrm{G}>\mathrm{A}$ and g.65340727T $>$ C polymorphisms were identified. In the $2^{\text {nd }}$ exon of the GDF5 gene, the $g .65340902 \mathrm{~A}>\mathrm{G}$ polymorphism was identified. No polymorphism was found in the examined $2^{\text {nd }}$ intron region of the $G D F 5$ gene. As a result, new polymorphic regions were detected on EPS 8 and GDF5 genes by HRMA, genotype and allele gene frequencies of polymorphic regions were determined. Hardy-Weinberg equilibrium test generally shown that the distribution of genotype frequencies in polymorphic regions is in genetic equilibrium.
\end{abstract}

Article Information
Received 15 June 2020
Revised 02 August 2020
Accepted 27 August 2020
Available online 23 July 2021
Authors' Contribution
MO and ZS planned the study. MO
collected the samples. ZS designed the
primers. ZS and MO collected data
and analyzed. MO wrote the article.
Key words
EPS8, GDF5, HRMA, Polymorphism,
Cattle.

Cattle.

\section{INTRODUCTION}

$\mathrm{N}$ ew genetic markers can be used in indirect selection to increase the yield of livestock in terms of quality and quantity. For this purpose, linkage maps are created to identify monogenic characters inherited by a single gene, and QTL (quantitative trait locus) maps are created to identify multiple phenotypes that are inherited by the effect of the environment and genes (Wang, 2012).

A total of 99652 QTL were identified on a total of 29 chromosomes and X chromosome from 799 different publications showing 574 different characteristics on cattle (Hu et al., 2016). A total of 34927 QTL related to the milk were identified, including 16390 related to the milk protein ratio, 13391 related to the fat ratio in the milk, 3243 for the percentage of fat in the milk, 3764 related to the milk yield, and 296 effective in the milk formation ( $\mathrm{Hu}$ et al., 2016).

The EPS8 gene (EGF receptor pathway substrate 8), identified as the first member of the EPS8 gene family, is located on the $5^{\text {th }}$ chromosome in the cattle and

\footnotetext{
Corresponding author: ozdemirm@atauni.edu.tr 0030-9923/2021/0005-1857 \$ 9.00/0

Copyright 2021 Zoological Society of Pakistan
}

contains 26 exons (Anonymous, 2018a). In a study conducted by Wang (2012) to identify QTL regions affecting the fat percentage in the milk in the German Holstein-Friesian (HF; 2327 progeny-test) population and to link it with the genome, 44280 SNPs were identified, and the QTL EPS8 and GPAT4 genes were found to be involved in mammalian lipid metabolism, 50 polymorphisms were observed as a result of the re-sequencing in the EPS 8 and GPAT4 genes, and the two promoter polymorphisms (ss319604831 and ss319604833) observed in the EPS8 and GPAT4 gene regions were found to have a significant effect on the fat percentage. Due to their effect on the synthesis of non-esterified fatty acids (NEFA) and liver triacylglycerol, it was concluded that they increase the fat biosynthesis in the milk in the mammary glands during lactation. For these reasons, it is thought that polymorphic regions on the gene may affect some economic traits.

It was reported that the EPS 8 gene has an effect on the milk yield in cattle, and since the EPS 8 gene, which acts as an epidermal growth factor receptor (EGFR) tyrosine kinase substrate, increases signaling pathways responsible for the epidermal growth factor, it affects the milk yield in dairy cattle breeds (Raven et al., 2014).

Growth/differentiation factor-5 (GDF5) gene 
synthesizes protein with a weight of $75 \mathrm{kD}$ in the region containing 2 exons on the 5th chromosome in cattle (Anonymous, 2018b).

Liu et al. (2010) identified the T586C polymorphism in exon 1 as a result of the analyses performed in their studies on the effect of the GDF5 gene polymorphism on body size in cattle, and they suggested that the effect of the TT, TC and CC genotypes identified on body length and hip width properties was very significant $(\mathrm{P}<0.01)$ and that the GDF5 gene could be used as a growth marker in selection programs.

A high-resolution melting analysis (HRMA) represents the easiest method of genotyping and mutation detection since it is performed in the same tube and just after the PCR procedure (Montgomery et al., 2007). The HRM analysis described in this report provides an alternative approach to traditional genotyping for SNPs/ polymorphism in the improvement of bovine production traits, and it has many advantages, including speed, expense, and accuracy. This method can also be very useful in assessing the efficiency of nuclear transfer as well as in studies of nuclear-cytoplasm interactions and maternal effects on cloned embryos.

In the present study, it was aimed to determine novel polymorphisms in GDF5 (growth differentiation factor 5 (CDMP-1)) and EPS8 (epidermal growth factor receptor substrate 8).

\section{MATERIALS AND METHODS}

Blood samples of 72 head Holstein cows reared under organic condition in the Kelkit region of Gumushane in Turkey were used as material. Genomic DNA was extracted from the whole blood samples using a Purgene kit (Gentra Systems, Plymouth, MN, USA).

Three pairs of primers were designed for the GDF5 (NCBI Reference Sequence: AC 000170.1) and EPS8 (NCBI Reference Sequence: AC_000162.1) genes that were used in the present study using Primer 3 Software (Rozen and Skaletsky, 2000) (Table I).

\section{PCR and HRMA}

PCR was performed to replicate the related gene region of the obtained DNA, the qualitative and quantitative controls of the analysis results were carried out by $2 \%$ agarose gel electrophoresis. Amplifications were performed on the Rotor-Gene Q 2plex HRM Platform. The reaction mixture contained $2 \mathrm{mM} \mathrm{MgCl} 2,1 \mu \mathrm{l}$ of each dNTP (D7595: Sigma, St. Louis, MO, USA), $0.2 \mu \mathrm{M}$ of each primer, $1 \times$ PCR buffer, $1 \mathrm{U}$ Taq polymerase (D1806; Sigma) and $50 \mathrm{ng}$ of genomic DNA template in a total volume of $25 \mu \mathrm{l}$. The HRM analysis was carried out using a fluorescent dye EvaGreenTM $(2 \mu \mathrm{M})$ (Quantace, UK). All samples were repeated in duplicate. The amplification program consisted of an initial denaturation of $94^{\circ} \mathrm{C}$ for $5 \mathrm{~min}$ followed by 40 cycles of $94^{\circ} \mathrm{C}, 58^{\circ} \mathrm{C}$, and $72^{\circ} \mathrm{C}$ $\left(25 \mathrm{~s}\right.$ each) and a final extension for $5 \mathrm{~min}$ at $72^{\circ} \mathrm{C}$. After amplification, the melting analysis was immediately performed. Based on the normalized Tm curves, the samples were clustered according to the principal component analysis (Reja et al., 2010) in the unsupervised mode using the Rotor-Gene ScreenClust HRM Software program in order to determine differences between the samples.

Table I.- List of primers used for HRMA in the EPS8 and GDF5 genes.

\begin{tabular}{|c|c|c|c|c|c|}
\hline Gene & Region & Primer sequence 5' to $3^{\prime}$ & Base positions & Amplicon (bp) & Annealing tm $\left({ }^{\circ} \mathrm{C}\right)$ \\
\hline \multirow[t]{6}{*}{ EPS8 } & $1^{\text {st }}$ exon & F:CCTTTGTGTGCCGAGATGGA & $334-833$ & 500 & 60 \\
\hline & & R:CCGAGTGAAGCCGCTAAGAA & & & \\
\hline & $1^{\text {st }}$ exon & F:GATCCCGCCATCGTATACCC & $729-1120$ & 392 & 57 \\
\hline & & R:TCTACCGCTCTTGACGCCTA & & & \\
\hline & $2^{\text {nd }}$ exon & F:CGTTGCACTCAGTTGTCACA & $2172-2512$ & 341 & 58 \\
\hline & & R:GCCTATCCCTTCTCCAGCAT & & & \\
\hline \multirow[t]{6}{*}{ GDF5 } & $1^{\text {st }}$ exon & F:CCAGCCCATGTCCTTGAAGT & $396-766$ & 371 & 60 \\
\hline & & R:GGGAGGTGTTCGACATCTGG & & & \\
\hline & $2^{\text {nd }}$ exon & F:CCAGATGTCGAACACCTCCC & $747-1310$ & 564 & 61 \\
\hline & & R:GGCAGGAGGCAGTTCTAAGG & & & \\
\hline & $2^{\text {nd }}$ intron & F:ATCTCAGATGCCCATGGTTC & $1019-1287$ & 268 & 56 \\
\hline & & R:AGGGCTCTCAGAAGTCACCA & & & \\
\hline
\end{tabular}



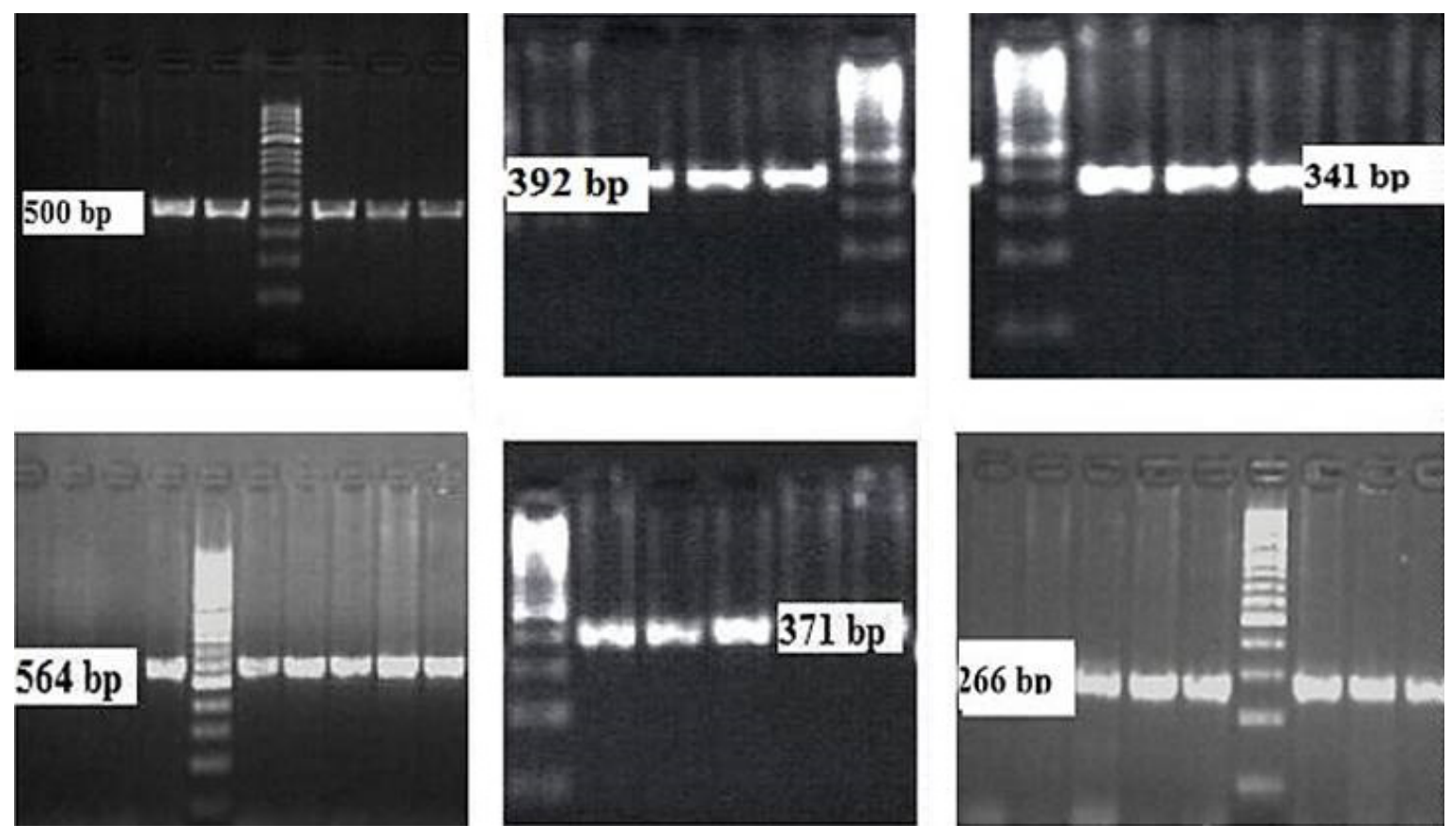

Fig. 1. Agarose gel images of the PCR results of the EPS 8 and GDF5 gene regions.

\section{HRMA data and normalization}

The PCRs of the samples, of which HRM analyses were performed for different gene regions using the Rotor Gene Q real-time PCR device, were performed using EvaGreen intercalation dye, and while the amplicons were transformed into a single chain form by denaturation in such a way that the temperature degrees gradually increased, the HRMA graphs were determined according to the amount of fluorescent light emitted by each sample. As a result of the HRMA graphs, the melting temperatures of PCR amplifications were determined, and the samples without PCR and fluorescence were excluded.

Since differences in fluorescence in the raw HRM analysis can be induced by different factors in the PCR and HRM process, for example, different amounts of amplicons and template DNA, any HRM analysis start and end fluorescence should be normalized. The normalization interval was used to calculate the average fluorescence value and the slope of the curve in the regions before and after the melting curve transition, with the highest fluorescence value equal to 100 and the lowest value equal to zero. Based on the temperature ranges in which the melting peaks were observed, samples without PCR were excluded, and normalization graphs were determined.

\section{DNA sequencing}

A total of 72 PCR samples were separated into clusters by the HRM method, and randomly 4 samples from each cluster were selected for the DNA sequence analysis and sent to the company that performs commercial DNA sequencing to obtain a DNA base sequence of each sample. Subsequently, the genotype differences of the samples according to the DNA sequence results were compared with the help of Mega 7.0 (Kumar et al., 2016) and BioEdit 7.2.6 (Hall, 2005) programs.

\section{RESULTS AND DISCUSSION}

The agarose gel images of the PCR result of the gene regions are presented in Figure 1.

\section{HRM analysis results and normalization graphs}

The HRMA analysis of the 72 DNA samples of Holstein cattle was performed using Eva Green DNA saturation dye, and their normalization intervals were determined based on the melting curve temperatures determined according to the raw HRM analysis graph, and normalization graphs in the specific temperature range of the regions were obtained (Fig. 2).

\section{HRM cluster analysis}

In order to determine the HRM profiles of the GDF5 and EPS8 genes, HRM-PCR of the 72 DNA samples of Holstein cattle was performed in a closed tube environment using EvaGreen intercalation dye. As a result of the clustering analysis of the 72 DNA samples 
of Holstein cattle, of which HRM-PCR analysis was performed, they were clustered according to their melting curve differences. The data evaluated on the ScreenClust HRM software were collected in different clusters for each region according to the three-dimensional principal component analysis (PCA) (Fig. 3).

As a result of the HRM-PCR analyses, in the 72 samples belonging to Holstein cattle, the number of different clusters formed was 8 for the $E P S 8$ gene $1^{\text {st }}$ exon $1^{\text {st }}$ region and 9 for the $2^{\text {nd }}$ region, 9 for the $E P S 82^{\text {nd }}$ exon, 7 for the GDF5 gene $1^{\text {st }}$ exon region and 8 for the $2^{\text {nd }}$ exon region, and 6 for the $2^{\text {nd }}$ intron region. Sequence analyses were obtained by randomly taking 4-6 samples from each of these clusters with more than 5 samples, and taking all samples from the clusters with less than 5 samples.
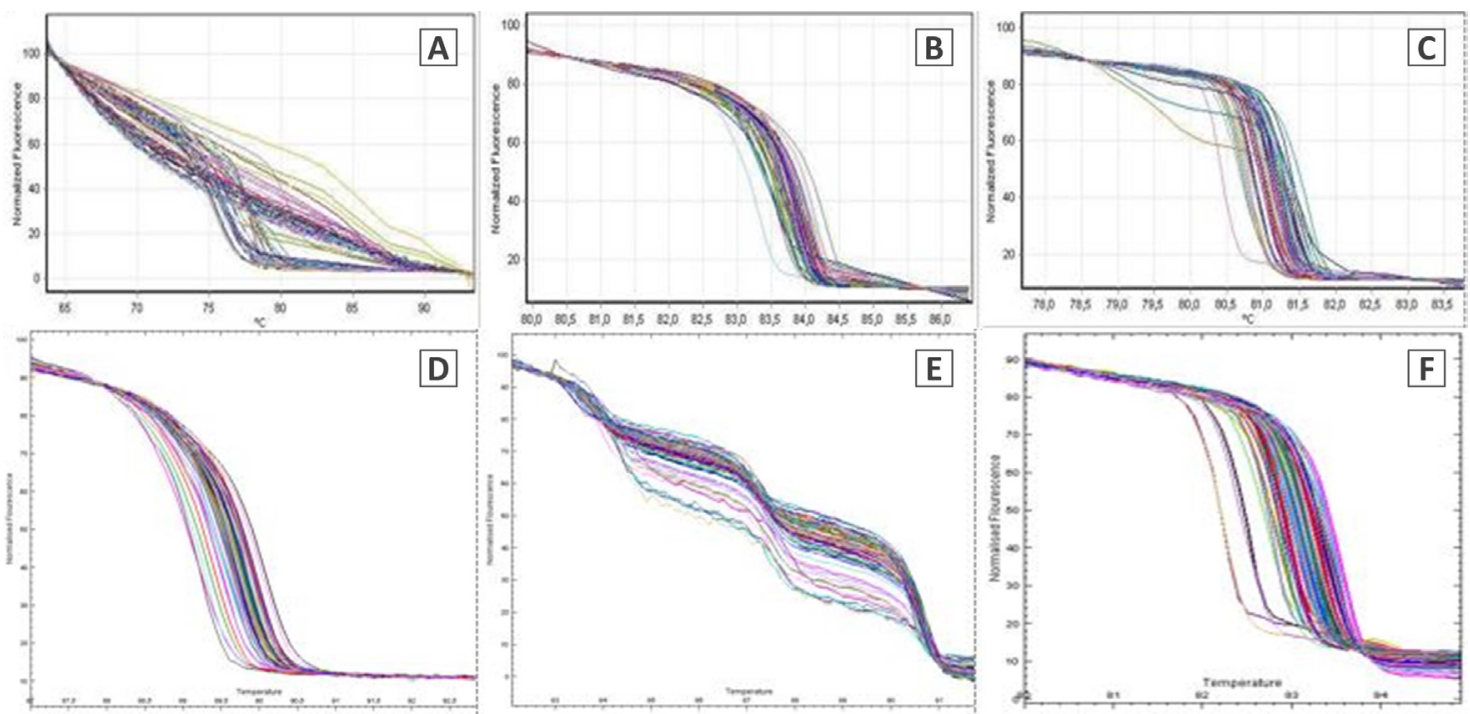

Fig. 2. Normalized high resolution melting curves. A, EPS8 exon 1_1; B, EPS8 exon 1_2; C, EPS8 exon 2; D, GDF5 exon 1; E, GDF5 exon 1; F, GDF5 intron 2.
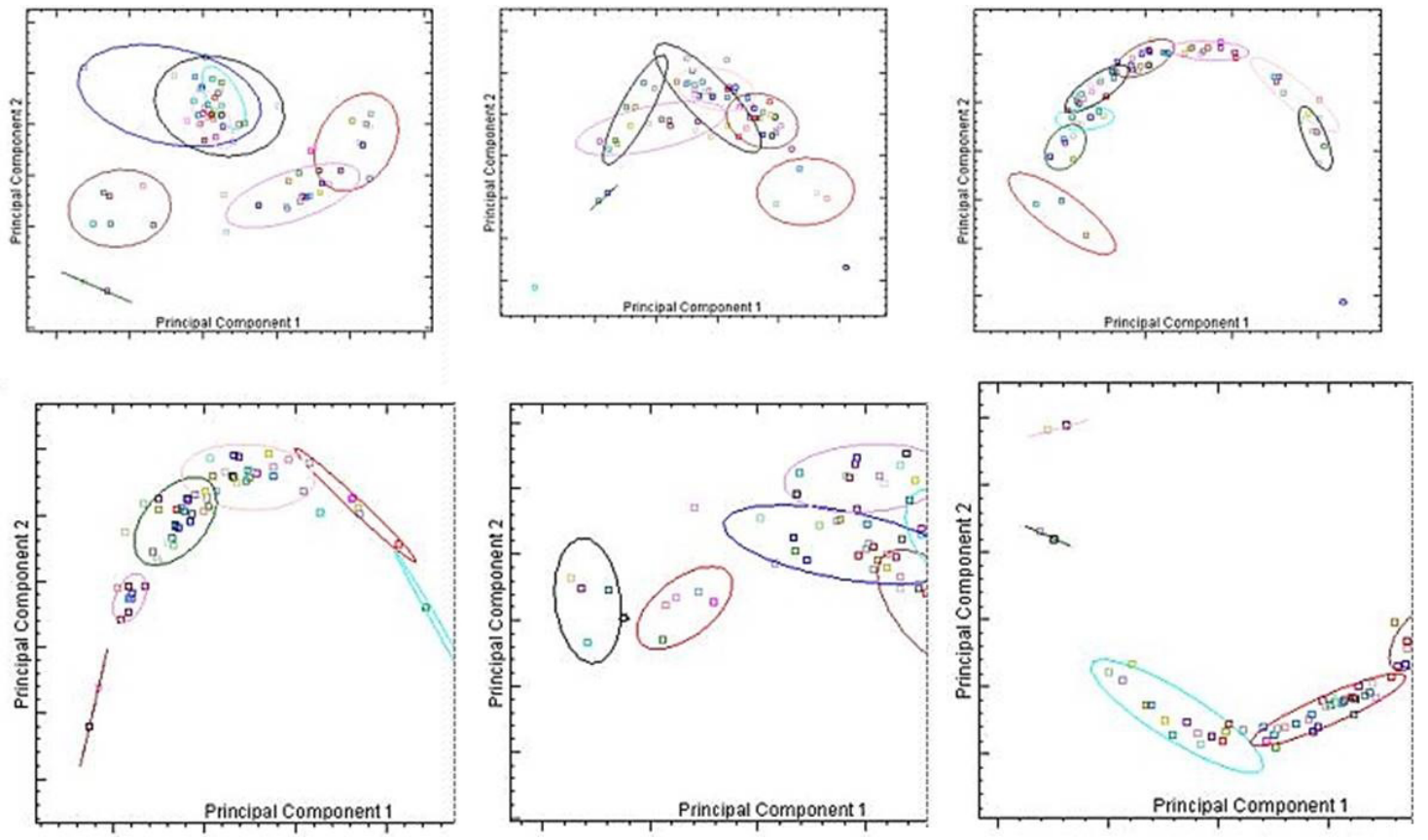

Fig. 3. The clusters by PCA of HRMA of the gene regions. 


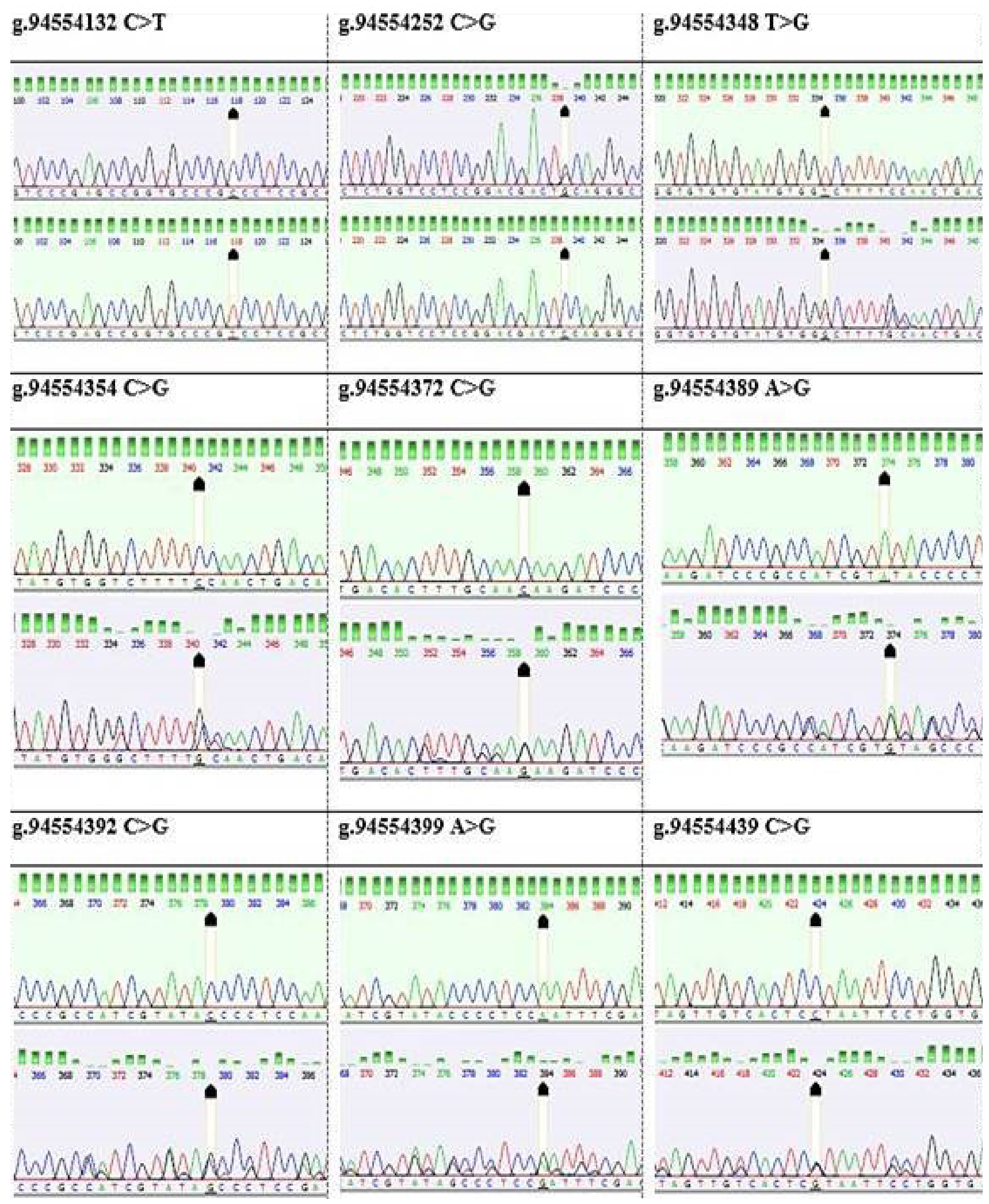

Fig. 4. Polymorphic sites in EPS8 exon 1. 
Table II.- Polymorphic regions and marker positions in the EPS8 and GDF5 genes, the amino acid substitution and genotype frequencies, and Hardy-Weinberg genetic equilibrium test results.

\begin{tabular}{|c|c|c|c|c|c|c|}
\hline Region & Marker position & $\begin{array}{l}\text { Amino acid } \\
\text { substitution }\end{array}$ & $\begin{array}{l}\text { Genotype counts } \\
\text { (AA:AB:BB)* }\end{array}$ & $\begin{array}{l}\text { Extended counts } \\
\text { (AA:AB:BB)* }\end{array}$ & $\begin{array}{c}\mathrm{H}-\mathrm{W} \\
\mathrm{X}^{2} \text { test }\end{array}$ & P value \\
\hline \multirow[t]{9}{*}{ EPS8 exon 1} & g.94554132 $\mathbf{C}>\mathrm{T}$ & Pro51Ser & $29: 2: 6$ & 48:07:17 & 41.730 & $0.000 * *$ \\
\hline & g. $94554252 \mathbf{C}>\mathrm{G}$ & Pro91Ala & $35: 2: 0$ & 58:14:00 & 0.835 & $0.361 \mathrm{~ns}$ \\
\hline & g.94554348 $\mathbf{T}>\mathrm{G}$ & Ser123Ala & $30: 6: 0$ & $56: 16: 00$ & 1.125 & $0.289 \mathrm{~ns}$ \\
\hline & g.94554354 C $>$ G & Pro125Ala & $31: 5: 0$ & $56: 16: 00$ & 1.125 & $0.289 \mathrm{~ns}$ \\
\hline & g. $94554372 \mathbf{C}>\mathrm{G}$ & Gln131Glu & $29: 5: 0$ & $56: 16: 00$ & 1.125 & $0.289 \mathrm{~ns}$ \\
\hline & g.94554389 $\mathbf{A}>\mathrm{G}$ & Val136Val & $29: 5: 0$ & $62: 10: 00$ & 0.401 & $0.527 \mathrm{~ns}$ \\
\hline & g.94554392 $\mathbf{C}>\mathrm{G}$ & Tyr137Stop & $29: 5: 0$ & $56: 16: 00$ & 1.125 & $0.289 \mathrm{~ns}$ \\
\hline & g.94554399 $\mathbf{A}>\mathrm{G}$ & Asn140Asp & $30: 4: 0$ & $62: 10: 00$ & 0.401 & $0.527 \mathrm{~ns}$ \\
\hline & g.94554439 C $>\mathrm{G}$ & Pro153Arg & $30: 4: 0$ & $56: 16: 00$ & 1.125 & $0.289 \mathrm{~ns}$ \\
\hline EPS8 exon 2 & g. $94555920 \mathbf{T}>\mathrm{G}$ & Ser132Ala & $26: 13: 0$ & 52:19:00 & 1.694 & $0.193 \mathrm{~ns}$ \\
\hline \multirow[t]{2}{*}{ GDF5 exon 1} & g. $65340723 \mathbf{G}>A$ & Val198Ile & $16: 4: 1$ & $51: 11: 05$ & 0.587 & $0.443 \mathrm{~ns}$ \\
\hline & g.65340727 T>C & Leu199Pro & $18: 1: 2$ & 60:09:00 & 0.336 & $0.562 \mathrm{~ns}$ \\
\hline$G D F 5$ exon 2 & g.65340902 A>G & Gly257Gly & $15: 14: 1$ & $18: 31: 20$ & 0.699 & $0.403 \mathrm{~ns}$ \\
\hline
\end{tabular}

**, $\mathrm{p}<0.01$, ns: non-significant $(\mathrm{p}>0.05)$. ${ }^{*}$ Note, genotype counts were calculated based only on the DNA sequencing results, the symbols here are representative.

\section{DNA sequencing}

DNA sequence analysis results were evaluated to identify the regions showing polymorphism in the EPS8 and GDF5 gene regions in Holstein cattle, and the results are presented in images and graphs.

After the comparison of the DNA sequence analyses of 37 samples taken from 8 clusters in the EPS 8 gene $1^{\text {st }}$ exon region (NCBI accession: AC_000162 region: 94553980-94554479) in Holstein cattle, $500 \mathrm{bp}$ in length of which PCR analysis was performed, 185 base differences were determined, and 7 haplotypes were detected. Upon examining these haplotypes, as a result of the DNA sequence analysis, a total of 9 polymorphic regions were identified, including g.94554132 $\mathrm{C}>\mathrm{T}$, g.94554252 G>C, g.94554348 T $>$ G, g.94554354 $\mathrm{C}>\mathrm{G}$, g.94554372 C $>$ G, g.94554389 A $>$ G, g.94554392 $\mathrm{C}>\mathrm{G}$, g.94554399 A $>$ G, g.94554439 $\mathrm{C}>\mathrm{G}$. Base substitutions caused codon differentiations in the gene region, and the substitutions of g.94554132 C>T and CCC- $\underline{\mathbf{T C C}}$ Proline51-Serine (Pro51Ser), g.94554252 G>C GCACCA Proline91-Alanine (Pro91Ala), g.94554348 T $>\mathrm{G}$ TCT-GCT Serine123-Alanine (Ser123Ala), g.94554354 $\mathrm{C}>\mathrm{G}$ GCA-CCA Proline125-Alanine (Pro125Ala), g.94554372 C>G GAA-CAA Glutamine131- Glutamic

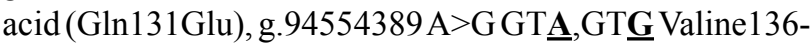
Valine (Val136Val), g.94554392 C $>\mathrm{G}$ TACE-TA $\underline{\mathbf{G}}$ Tyrosine137-Stop (Tyr137STP), g.94554399 A $>$ G $\underline{\text { AAT- }}$ GAT Asparagine140-Aspartic (Asn140Asp), g.94554439

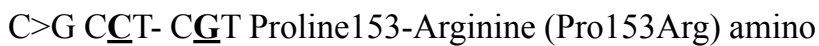
acids occurred. Alleles of the polymorphic regions, amino acid substitutions and genotype frequencies are presented in Table II. The distribution of genotype frequencies in polymorphic regions is in Hardy-Weinberg genetic equilibrium but except first (Table II).

\section{g.94555920 T>G}

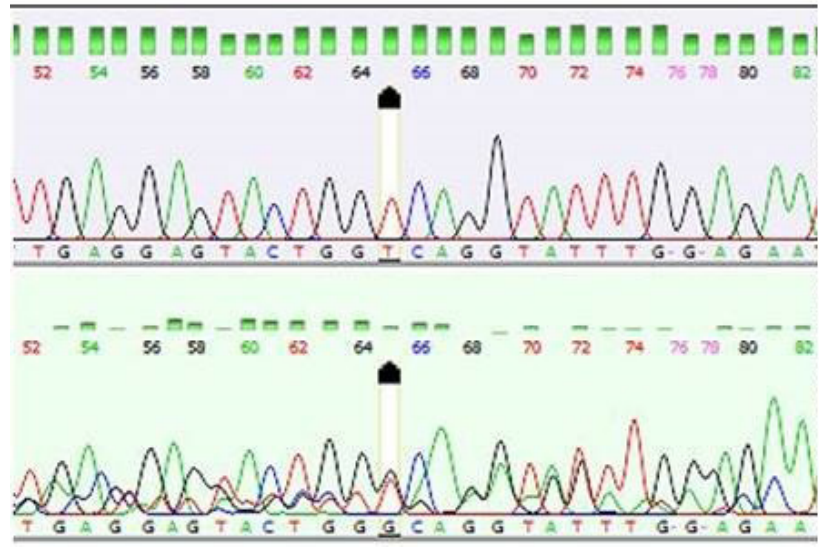

Fig. 5. Polymorphic site in EPS8 exon 2.

SNPs presented in the NCBI dbSNP database were reviewed to compare the SNP similarities, identified for the EPS8 gene in Bos taurus cattle of the polymorphic 
regions identified on the 1st exon region of the EPS8 gene. In accordance with the NCBI data, it was determined that the g.94554132 $\mathrm{C}>\mathrm{T}$ polymorphic region (RefSNPrs134033930) and g.94554252 G $>$ C SNP (RefSNP-rs rs 135284172) had been identified by previous studies (Kawahara et al., 2011; Jansen et al., 2013). However, it was determined that the g.94554348 T>G, g.94554354 $\mathrm{C}>\mathrm{G}$, g.94554372 C>G, g.94554389 A $>\mathrm{G}$, g.94554392 $\mathrm{C}>\mathrm{G}$, g.94554399 A $>\mathrm{G}$, g.94554439 $\mathrm{C}>\mathrm{G}$ polymorphic regions or the SNP close to these regions were not identified.

\section{g.65340723 G>A}
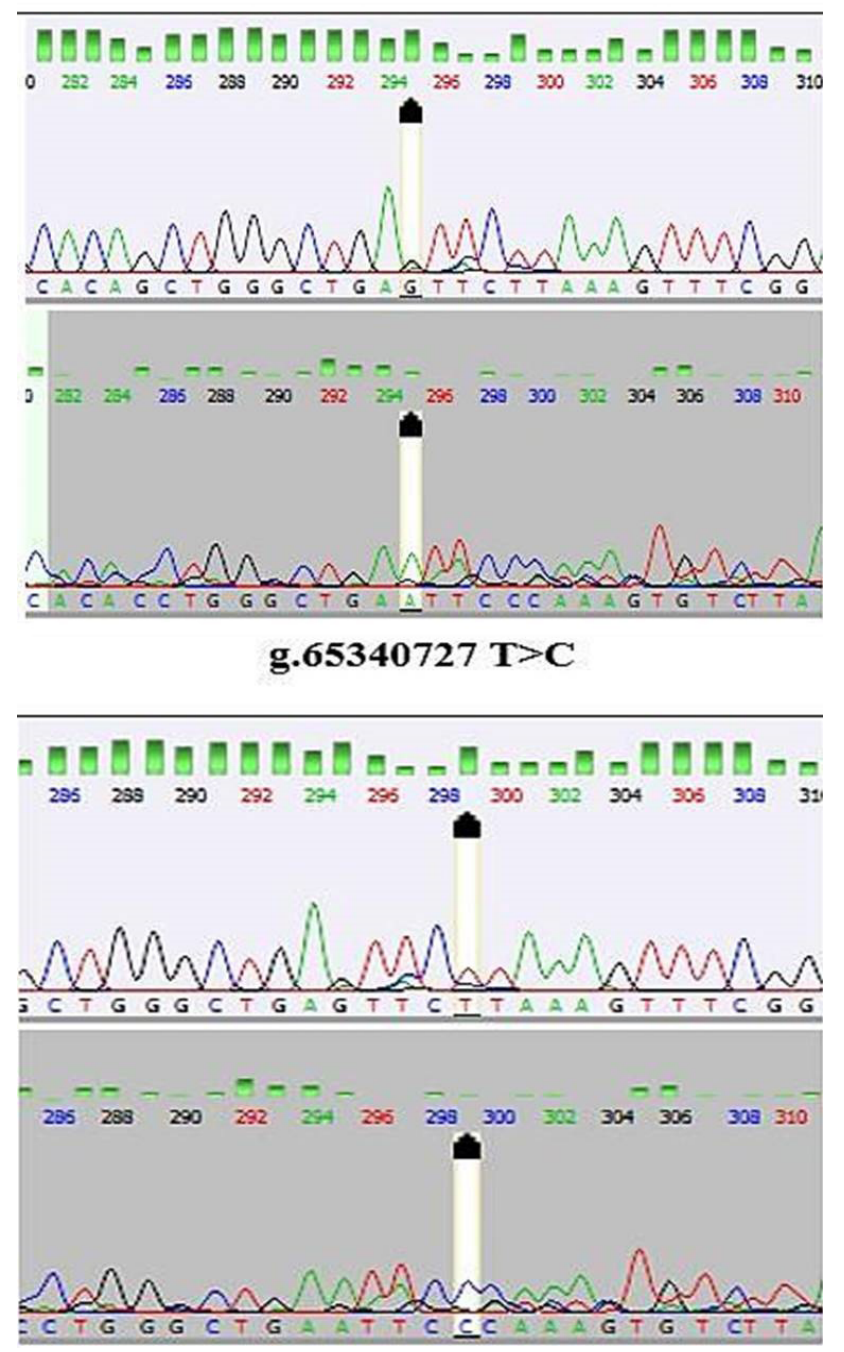

Fig. 6. Polymorphic sites in GDF5 exon 1.

A total of 95 base substitutions were detected in 35 samples of which sequence analysis was performed for the $1^{\text {st }}$ exon- $2^{\text {nd }}$ region of the EPS 8 gene 392 bp in length.
Polymorphic regions were not detected between the sequences with base substitutions.

In 39 samples, a total of 223 single base substitutions were detected for the $2^{\text {nd }}$ exon region of the EPS 8 gene. Among these base substitutions, the g.94555920 $\mathrm{T}>\mathrm{G}$ polymorphic region was identified, and $13 \mathrm{TG}$ and $26 \mathrm{TT}$ genotypes were obtained. As a result of the DNA sequence substitutions of the bases of which multi-protein sequence analysis was performed and the DNA sequence analysis on the $2^{\text {nd }}$ exon region of the EPS8 gene $321 \mathrm{bp}$ in length in Holstein Cattle, g.94555920 $\mathrm{T}>\mathrm{G}$ base substitutions caused TCA-GCA codon differentiations and Serine132Alanine (Ser132Ala) amino acid substitution.

The SNPs presented in the NCBI dbSNP database were checked to compare the SNP similarities for the g.94555920 $\mathrm{T}>\mathrm{G}$ polymorphic region gene, of which EPS8 gene $2^{\text {nd }}$ exon region was identified, in Bos taurus cattle. In accordance with the NCBI data, it was determined that $\mathrm{SNP}$ close to the g.94555920 $\mathrm{T}>\mathrm{G}$ polymorphic region was not identified.

\section{g.65340902 $\mathrm{A}>\mathrm{G}$}
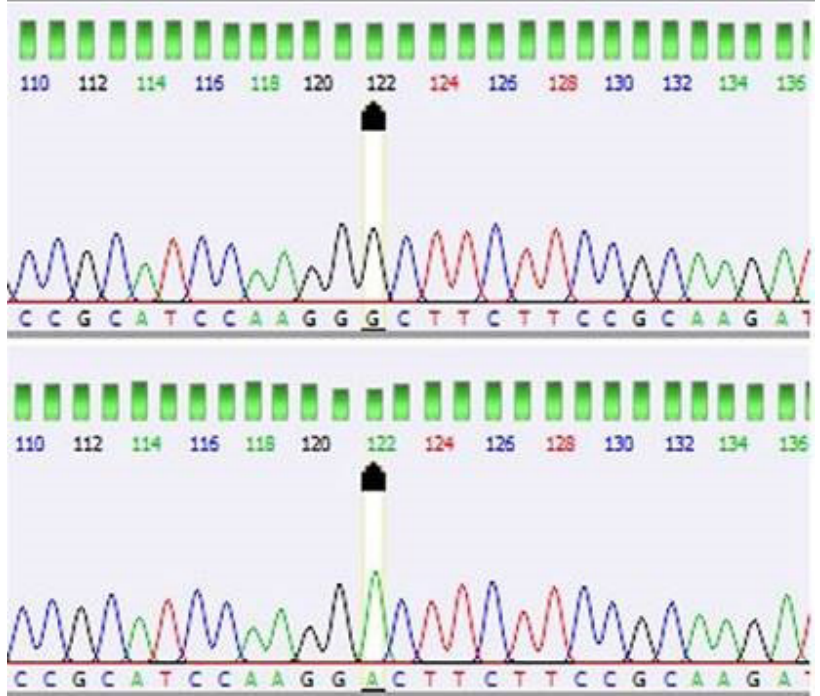

Fig. 7. Polymorphic site in GDF5 exon 2.

As a result of the DNA sequence analyses of the 28 samples, of which sequencing was performed for the $1^{\text {st }}$ exon region of the GDF5 gene (Accession: AC_000170, region: 65340396-65340766), the g.65340723 $\overline{\mathrm{G}}>\mathrm{A}$ and g.65340727 $\mathrm{T}>\mathrm{C}$ polymorphic regions were identified. In the g.65340723 $\mathrm{G}>\mathrm{A}$ region, $1 \mathrm{AA}, 4 \mathrm{GA}$, and $16 \mathrm{GG}$ genotypes were identified, while in the g.65340727 $\mathrm{T}>\mathrm{C}$ polymorphic region, $2 \mathrm{CC}, 1 \mathrm{TC}$, and $18 \mathrm{TT}$ genotypes were identified. g.65340723 G>A $\underline{\text { GTT- }}$ ATA Valine198- 
Isoleucine (Val198Ile) and g.65340727 T $>C$ base substitutions for the $1^{\text {st }}$ exon region of the GDF5 gene 371 bp in length caused CIA-C $\underline{\mathbf{C} A}$ codon differentiations and Leucine199-Proline (Leu199Pro) amino acid substitutions occurred.

According to the PCR results on 42 Holstein cattle breed samples for the $1^{\text {st }}$ exon of the EPS 8 gene $\mathrm{g} .94554132$ $\mathrm{C}>\mathrm{T}$, g.94554252 G>C, g.94554348 T>G, g.94554354 $\mathrm{C}>\mathrm{G}, .94554372 \quad \mathrm{C}>\mathrm{G}, \quad$ g.94554389 $\mathrm{A}>\mathrm{G}, \quad$ g.94554392 $\mathrm{C}>\mathrm{G}$, g.94554399 A $>\mathrm{G}$, g.94554439 $\mathrm{C}>\mathrm{G}$ polymorphic regions and for the $2^{\text {nd }}$ exon region of the EPS8 gene 321 bp in length in Holstein Cattle, g.94555920 T>G were identified and genotypes were clustered by using ScreenClust software. Thus, altogether 72 DNA samples were genotyped. It was determined that sequencing and clustering analyses mostly showed similar results.

SNPs presented in the NCBI dbSNP database were checked to compare the SNP similarities, identified for the GDF5 gene in Bos taurus cattle of the g.65340723 G>A and g.65340727 $\mathrm{T}>\mathrm{C}$ polymorphic regions identified on the $1^{\text {st }}$ exon region of the GDF5 gene. In accordance with the NCBI data, it was determined that the closest GCF_000 003055.4:Chr13:g.65340720T >C (RefSNP-rs455694222) SNP was reported by Cofactor-Genomics company (2013) at a distance of $3 \mathrm{bp}$ to the $\mathrm{g} .65340723 \mathrm{G}>$ A polymorphism. The same company (2013) reported GCF_000003055.4:C hr13:g.65340729A $>$ C (RefSNP-rs475666127) SNPs for the g.65340727 $\mathrm{T}>\mathrm{C}$ SNP region.

185 mutant bases were identified for the GDF5 $2^{\text {nd }}$ exon region (Accession: AC_000170 region: complement 65340132:65343889) 564 bp in length, of which sequencing was performed, on the 40 DNA samples of Holstein cattle, and the g.65340902 A>G polymorphic region was identified and $1 \mathrm{AA}, 14 \mathrm{GA}$ and $15 \mathrm{GG}$ genotype frequencies were determined. As a result of the g.65340902 $\mathrm{A}>\mathrm{G}$ transitional base substitution, GG $\underline{\mathbf{A}}$ GGE codon differentiation and Glycine257-Glycine (Gly257Gly) amino acid substitution were caused.

As a result of the comparison analysis of the similarities of the SNPs presented in the NCBI dbSNP database, identified for the GDF5 gene in Bos taurus cattle of the g.65340902 $\mathrm{A}>\mathrm{G}$ polymorphic region identified on the $2^{\text {nd }}$ exon region of the GDF5 gene, according to the NCBI data, it was determined that the g.65340902 A>G polymorphism (RefSNP-rs208187104; rs208187104) had been identified in previous studies (Stothard et al., 2011; Jansen et al., 2013).

A total of 46 mutant bases were identified for the $2^{\text {nd }}$ intron region of the GDF5 gene (Accession: AC 000170 Region: 65341151. 65341401) $250 \mathrm{bp}$ in length, as a result of the analysis of 29 DNA sequences of which sequence analysis was performed, but no sequences showing polymorphism between these mutant bases were found.

\section{CONCLUSION}

As a result, a total of 13 polymorphic regions were identified, including 9 different polymorphic regions for the EPS 8 gene $1^{\text {st }}$ exon $1^{\text {st }}$ region and 1 for $2^{\text {nd }}$ exon region, and 2 for the GDF5 gene $1^{\text {st }}$ exon region and 1 for the $2^{\text {nd }}$ exon region. The g.94554348 $\mathrm{T}>\mathrm{G}$, g.94554354 $\mathrm{C}>\mathrm{G}$, g.94554372 $\mathrm{C}>\mathrm{G}$, g.94554389 A $>\mathrm{G}$, g.94554392 $\mathrm{C}>\mathrm{G}$, g.94554399 A $>$ G, g.94554439 $\mathrm{C}>\mathrm{G}$ polymorphic regions for the EPS 8 gene $1^{\text {st }}$ exon $1^{\text {st }}$ region, g.94555920 $\mathrm{T}>\mathrm{G}$ polymorphic region for the EPS 8 gene $2^{\text {nd }}$ exon region, and g.65340723 $\mathrm{G}>\mathrm{A}$ and g.65340727 $\mathrm{T}>\mathrm{C}$ polymorphic regions (SNPs) for the GDF5 gene $1^{\text {st }}$ exon region were identified for the first time in this study.In studies to be conducted on animal breeding, HRMA can be suggested to investigate the effects of identified polymorphic regions on different breeds and with different performance traits and their ability to become markers in breeding programs.

\section{ACKNOWLEDGEMENT}

This study was supported by Ataturk University Scientific Research Projects Fund (Project No. 2015/400). We gratefully thank Ataturk University SRP Foundation.

Statement of conflict of interest

The authors declare no conflict of interest.

\section{REFERENCES}

Anonymous, 2018a. OMIM: Online Mendelian Inheritance in Man, registered trademarks of the Johns Hopkins University. 1966-2020 Johns Hopkins University. http:/www.omim.org/entry (Accessed on 12 Dec, 2017).

Anonymous, 2018b. Gene. National Center for Biotechnology Information, U.S. National Library of Medicine 8600 Rockville Pike, Bethesda MD, 20894 USA. Available at: http://www.ncbi.nlm.nih. gov/gene (Accessed on 29 August, 2020).

Erlacher, L., McCartney, J., Piek, E., Dijke, P., Yanagishita, M., Oppermann, H. and Luyten, F.P., 1998. Cartilage-derived morphogenetic proteins and osteogenic protein-1 differentially regulate osteogenesis. J. Bone Miner. Res., 13: 383-392. https://doi.org/10.1359/jbmr.1998.13.3.383

Grievink, H. and Stowell, K.M., 2008. Identification of ryanodine receptor 1 single-nucleotide polymorphisms by high-resolution melting using the LightCycler 480 system. Anal. Biochem., 374: 
396-404. https://doi.org/10.1016/j.ab.2007.11.019

Hall, T.A., 2005. BioEdit: A user-friendly biological sequence alignment editor and analysis program for Windows 95/98/NT. Nucl. Acids. Symp. Ser., 41: 95-98.

Hoffmann, M., Hurlebaus, J. and Weilke, C., 2007. Novel methods for high-performance melting curve analysis using the LightCycler 480 system. Biochemica, 1: 17-19.

Hu, Z.L., Carissa, A.P. and Reecy, J.M., 2016. Developmental progress and current status of the animal QTLdb. Nucl. Acids Res., 44: D827-D833. https://doi.org/10.1093/nar/gkv1233

Jansen, S., Aigner, B., Pausch, H., Wysocki, M., Eck, S., Benet-Paga, S.A., Graf, E., Wieland, T., Strom, T., Mettnger, T. and Fries, R., 2013. Assessment of the genomic variation in a cattle population by re-sequencing at low coverage. BMC Genom., 14: 446. https://doi.org/10.1186/1471-2164-14-446

Kawahara, M.R., Tsuda, K., Shiwa, Y., Arai-Kichise, Y. and Matsumoto, T., 2011. Whole-genome resequencing shows numerous genes with nonsynonymous SNPs in the Japanese native cattle Kuchinoshima-Ushi. BMC Genom., 12: 103. https://doi.org/10.1186/1471-2164-12-103

Kumar, S., Stecher, G. and Tamura, K., 2016. MEGA7: Molecular evolutionary genetics analysis, Version 7.0 for bigger datasets. Mol. Biol. Evol., 33: 18701874. https://doi.org/10.1093/molbev/msw054

Liu, Y.F., Zan, L.S., Li, K., Zhao, S.P., Xin, Y.P., Lin, Q., Tian, W.Q. and Wang, Z.W., 2010. A novel polymorphism of GDF5 gene and its association with body measurement traits in Bos taurus and Bos indicus breeds. Mol. Biol. Rep., 37: 429-434. https://doi.org/10.1007/s11033-009-9604-5

Merino, R., Macias, D., Ganan, Y., Economides, A.N., Wang, X., Wu, Q., Stahl, N., Sampath, K.T., Varona, P. and Hurle, J.M., 1999. Expression and function of $G D F-5$ during digit skeletogenesis in the embryonic chick leg bud. Develop. Biol., 206: 33-45. https://doi.org/10.1006/dbio.1998.9129

Montgomery, J., Wittwer, C.T., Palais, R. and Zhou, L., 2007. Simultaneous mutation scanning and genotyping by high-resolution DNA melting analysis. Nat. Protoc., 2: 59-66. https://doi. org/10.1038/nprot.2007.10

Offenhauser, N., Castelletti, D., Mapelli, L., Soppo, B.E., Regondi, M.C., Rossi, P., D'Angelo, E., Frassoni, C., Amadeo, A., Tocchetti, A., Pozzi,
B., Disanza, A., Guarnieri, D., Betsholtz, C., Scita, G., Heberlein, U. and di Fiore, P.P., 2006. Increased ethanol resistance and consumption in Eps8 knockout mice correlates with altered actin dynamics. Cell, 127: 213-226. https://doi. org/10.1016/j.cell.2006.09.011

Provenzano, C., Gallo, R., Carbone, R., di Fiore, P.P., Falcone, G., Castellani, L. and Alema, S., 1998. Eps8, a tyrosine kinase substrate, is recruited to the cell cortex and dynamic F-actin upon cytoskeleton remodeling. Exp. Cell Res., 242: 186-200. https:// doi.org/10.1006/excr.1998.4095

Raven, L.A., Cocks, B.G. and Hayes, B.J., 2014. Multibreed genome wide association can improve precision of mapping causative variants underlying milk production in dairy cattle. BMC Genom., 15: 62. https://doi.org/10.1186/1471-2164-15-62

Reja, V., Kwok, A., Stone, G., Yang, L., Missel, A., Menzel, C. and Bassam, B., 2010. ScreenClust: Advanced statistical software for supervised and unsupervised high resolution melting (HRM) analysis. Methods, 50: 10-14. https://doi. org/10.1016/j.ymeth.2010.02.006

Rozen, S. and Skaletsky, H.J., 2000. Primer3 on the WWW for general users and for biologist programmers. In: Bioinformatics methods and protocols: Methods in molecular biology (eds. S. Krawetz and S. Misener). Humana Press, Totowa, N.J., pp 365-386.

Stothard, P.M., Choi, J.W., Basu, U., Sumner-Thomson, J.M., Meng, Y., Liao, X. and Moore, S.S., 2011. Whole genome re-sequencing of Black Angus and Holstein cattle for SNP and CNV discovery. BMC Genom., 15: 559. https://doi.org/10.1186/14712164-12-559

Wang, X., 2012. Identification and characterization of candidate genes for complex traits in cattle. $\mathrm{PhD}$ thesis, Chair of Animal Breeding, Technische Universitat, München.

West, P.H., Abdelfattah, A., Chen, P., Allen, C., Parish, J., Ladher, R., Allen, S., MacPherson, S., Luyten, F.P. and Archer, C.W., 1999. Mechanisms of GDF5 action during skeletal development. Develop. Biol., 126: 1305-1315.

Wong, W.T., Carlomagno, F., Druck, T., Barletta, C., Croce, C.M., Huebner, K., Kraus, M.H. and di Fiore, P.P., 1994. Evolutionary conservation of the EPS8 gene and its mapping to human chromosome 12q23-q24. Oncogene, 9: 3057-3061. 